\title{
Need Assessment for the Professional Development of Teachers in Content Knowledge of Instructional Planning and Strategies
}

\author{
Sidra Rizwan* \\ Rehana Masrur $^{* *}$
}

\begin{abstract}
In 2009 the National professional standards were introduced for teachers in Pakistan to determine a nationwide quality of teaching. These standards focus on the quality of teacher preparation from this time onwards; the present study was initiated to determine the needs of the workforce who are already in the practical field and how they may achieve the established standard. Therefore, in the light of the prescribed standard "Instructional Planning and Strategies (IPS)"this article investigated the levels of content knowledge of IPS possessed by the teachers in secondary schools; it further determined the difference in the content knowledge levels of urban \& rural, male\& female teachers regarding IPS. It was a survey type quantitative study with a population spread of secondary school teachers (SSTs) working in the four provinces and Federal Capital. A multistage sampling procedure was adopted to collect data from 400 SSTs belonging to the population area. The need of the in-service teachers for acquiring content knowledge of IPS was gauged through a questionnaire based on seven indicators of content knowledge given in the professional standards; the teachers further prioritized their training needs in these defined areas. Moreover, data triangulation was done to ensure the validity of the study. The indepth analysis revealed that SSTs possessed different levels on each indicator of content knowledge of IPS but a meager number was competent in it. Independent sample "t-test" was applied to calculate the difference between content knowledge of IPS possessed by the male\& female, urban\& rural SSTs. Although there was no significant difference
\end{abstract}

\footnotetext{
${ }^{*}$ Lecturer, Secondary Teacher Education Department, AIOU, Islamabad, Email: sidra.rizwan@aiou.edu.pk

** Ex-Dean, Faculty of Education, AIOU, Islamabad
} 
between the content knowledge of male \& female, urban \& rural SSTs; they all fell back on each indicator of prescribed content knowledge of IPS given in the standard. Therefore, professional development trainings were recommended for the in-service SSTs according to their needs at regular intervals to keep them abreast with the latest initiatives in the field of education which may enable them to plan instructional strategies accordingly.

Keywords: need assessment, content knowledge of instructional planning \&strategies, professional standards, professional development 


\section{Introduction}

It is being widely acknowledged that quality education is the product of quality teaching which is associated with teachers in any educational institution. It is essential that the teachers should be effectively trained; the training needs of the teachers should be managed on an on-going basis to update their knowledge about the modern trends evolving in the educational domain.

In Pakistan the professional standards for teachers were introduced in 2009, as per standards, the content knowledge of instructional planning and strategies (IPS)is based on seven indicators related to the knowledge and understanding of teachers about planning instruction for daily classroom teaching, their ability to design short and long-term plans which are based on subject content, curriculum related goals, students relationship with community, the competence of teachers in using multiple strategies with respect to students' age to promote the problem solving and critical thinking skills(Ministry of Education, 2009). Theseindicators help to measure this component independently. The teachers need to be competent in all the seven indicators of this component to achieve the professional standard.

Our education system holds teachers responsible for ensuring quality education. The significance of teachers has increased manifold with the advent of educational excellence and quality. In this context Rao (2004), stated that globally the education sector has entered a never ending struggle for excellence and enhanced quality, in such a scenario visionary and professionally refined teachers can produce culturally civilized generation.

The contemporary education system demands coming generations to be proficient in sophisticated skills so they can be a part of knowledge based society, for that the teachers should be well trained for teaching students with diverse needs and styles of learning. No doubt, it is challenging for teachers to promote critical thinking and problem solving skills and at the same time impart difficult subject matter effectively, along with promoting regular skills. Therefore it is required of them to be experts in the subject and professionally competent to impart various teaching methods and tactics which cater for the diversified needs of students. 
According to Darling-Hammond (2003) the most prominent factor in school which influences students' performance is the quality of teaching delivered by the teachers. It was further suggested that a rigorous system of professional education and training is essential for effective teaching. Moreover, Eggen \& Kauchak (2001) focused on three components for studying teachers' subject knowledge. These are knowledge of: the subject content, pedagogy of content, general pedagogy. Knowledge with understanding is the prerequisite of teaching; for nobody can teach what they do not understand. They further elaborated that the teachers lacking pedagogy of content knowledge usually summarize information from textbooks or give insignificant theoretical descriptions. Thus, the knowledge of teacher contributes towards quality teaching and this knowledge has various dimensions.

Content knowledge of IPS is the pedagogical content knowledge which demands proper command of a certain topic and the way it should be delivered to the students comprehensively. The knowledge of pedagogical content relates to the delivery of the content in most understandable way by utilizing variety in presentation of the subject and realization of the difficulty level of certain topics. It is maintained that classroom teaching is directly related to the pedagogical knowledge level of the teacher, which is different from the knowledge of subject $\mathrm{s} / \mathrm{he}$ is teaching. Research has proven the importance of subject knowledge in quality teaching, but the mechanism of delivery of this subject knowledge is of crucial importance. The achievement levels of students can be improved by providing favorable classroom learning environment which an effective teacher can ensure by adopting and applying multiple plans and strategies.

According to Ukeje (2008), teacher is held directly responsible for the development of next generation more than the members of any other profession. Lee (2010) elaborated that the core of knowledge of IPS refers to the competency with which the teacher transfers subject knowledge in an understandable way to the students. This consolidates the premise that knowledge related to IPS content is the pedagogy used for the transfer of learning content. The characteristics of students must be kept in view while planning instruction, with other factors like particulars of subject matter, the prevailing curriculum, personal experiences of teacher, present teaching resources and the learning 
environment. An effective lesson plan demands integration and intelligent combination of all these factors.

In the words of Kardia \& Wright (2004) "Teaching requires skill, insight, intelligence, and diligence, and faculty struggle and succeed in a variety of ways to meet the challenges of the classroom." While seemingly both male and female teachers display these characteristics, but research has revealed that the ways in which they encounter challenges are different. Therefore, to improve the quality of teaching it is imperative to have the knowledge about the different ways in which both these genders teach. Moreover, Faculty Survey of Student Engagement (National Survey of Student Engagement, 2005) highlighted the different ways in which males and females teach. Kuh, Nelson Laird, \& Umbach (2004) stated "women are more likely than their counterparts to value and use effective educational practices" p. 29.

Beside gender location is another source of variation among teachers at different levels across the world. Teachers working in rural areas are up against the challenges of inadequate distribution of facilities and opportunities offered to them as compared to their counterparts in urban areas. Multiple researches have proven that teachers of urban areas come across ample opportunities of professional development as compared to those working in rural areas.

No matter what the situation in order to improve the quality of teaching; teachers must be professionally trained according to some defined standards which help to determine the quality in a standardized manner. This would enhance the level of professionalism and commitment in teachers' attitude. In the past years different researches have supported this claim.

Atta, Aziz, Hassan \& Ahmad (2012), conducted a study on "National Professional Standards for Teachers and Classroom Practices" they investigated the classroom teaching in public schools. The findings revealed that the public school teachers possessed adequate knowledge of the subject matter but were lacking in lesson planning and assessment techniques. They recommended that instructional planning should be made obligatory for all the teachers.

Another research by Shakir \& Adeeb (2014) on National professional standards showed that at secondary level male teachers were found comparatively more competent than their female counterparts. 
Contrary to this a study conducted by Nelson Laird, Garver, \& Niskodé, (2007) on gender gap submitted that as compared to male, the instructional planning of female teachers is relatively more activity oriented and less lecture based. Further, this gender gap may vary on the basis of different course characteristics being taught.

A related study by Amirali \& Halai (2010) revealed that teachers working in urban schools were more inclined towards the use of professional standards including instructional planning and strategies in the classroom as compared to the teachers working in the rural areas. In contrast to that Shambaugh (2008) found no significant difference between rural \& urban teachers on any of the school context based dependent variables.

In the light of literature review the researcher conducted a study which identified the gap between content knowledge of IPS of SSTs and the required professional standard; on the basis of the gap identification the researcher prioritized the professional development areas according to the indicators of content knowledge of IPS which need to be targeted in order to enhance the quality of teaching. No doubt IPS has been a part of pre-service as well as in-service teacher training programs but now is the time to align the professional development trainings with the prescribed standard of content knowledge of IPS so that the deficiencies in this area may be addressed appropriately for those who got pre-service training before the introduction of the professional standards in the country and presently they contribute significantly to the teaching force.

\section{Objectives}

The study aimed to:

1. Identify the gap between prevailing levels of content knowledge of IPS and the required level prescribed in the professional standard.

2. Prioritize the professional development areas according to the indicators of content knowledge of IPS for teachers teaching secondary classes.

3. Find the difference between content knowledge of IPS of male \& female teachers teaching secondary classes.

4. Find the difference between the content knowledge of IPS of urban $\&$ rural teachers teaching secondary classes. 


\section{Research Questions/ Hypotheses}

1.1. At what levels of content knowledge of IPS do teachers stand according to each indicator?

1.2. What is the difference between the prevailing levels and required standard of content knowledge of IPS on each indicator?

2. In which areas of content knowledge of IPS do the teachers need professional development?

3. $\mathrm{H}_{0}$ : There is no significant difference between the seven indicators of content knowledge of IPS of male and female teachers.

$4 \mathrm{H}_{0}$ : There is no significant difference between the seven indicators of content knowledge of IPS of urban and rural teachers.

\section{Methodology}

The study was conducted by using quantitative research approach. This approach was selected for hypotheses testing and ensuring wider generalize ability. A cross-sectional survey research design was used to present a 'snapshot' of the current situation at a given time that allows drawing conclusions across a large population.

\section{Population}

Table 1

Strata wise distribution of the target population of SSTs

\begin{tabular}{llllll}
\hline Gender & Male & \multicolumn{3}{c}{ Female } & Total \\
\hline Location & $\mathrm{U}$ & $\mathrm{R}$ & $\mathrm{U}$ & $\mathrm{R}$ & \\
\hline FC & 589 & 541 & 693 & 858 & 2,681 \\
Punjab & 18,957 & 40,165 & 18,502 & 21,137 & 98,761 \\
Sindh & 6,692 & 8,820 & 8,409 & 1,677 & 25,598 \\
KPK & 2,811 & 13,412 & 1,685 & 4,057 & 21,965 \\
Balochistan & 4,868 & 5,160 & 3,642 & 872 & 14,542 \\
Total & 33,917 & 68,098 & 32,931 & 28,601 & 163,547 \\
\hline
\end{tabular}

FC: Federal Capital, KPK: Khyber Pakhtunkhwa 


\section{Sampling}

Multistage sampling technique was used in the study. In the first stage convenient sampling was done to select a single district from every province along with Federal Capital. Moreover, in the second stage one Tehsil (Administrative Unit) was selected from each district and Federal Capital was treated as a whole. In stage three 80 secondary schools were selected through proportionate stratified sampling. In the fourth stage 5 teachers teaching secondary classes were selected randomly from each selected secondary school and overall a sample of 400 teachers teaching secondary classes was selected.

Random sampling was done through draw card method.

Table 2

Sample of the Study

\begin{tabular}{|c|c|c|c|c|c|c|c|c|c|c|c|c|c|}
\hline \multirow[t]{2}{*}{ Sample } & \multirow{2}{*}{$\frac{\text { Category }}{\text { Gender }}$} & $\mathrm{FC}$ & \multicolumn{3}{|c|}{ Rawalpindi } & \multicolumn{2}{|c|}{$\begin{array}{l}\text { Karachi } \\
\text { Central } \\
\end{array}$} & \multicolumn{2}{|c|}{ Abbottabad } & \multicolumn{2}{|c|}{$\begin{array}{c}\text { Zarghoon } \\
\text { Town }\end{array}$} & \multirow[t]{2}{*}{ Total } & \multirow[t]{2}{*}{ Size } \\
\hline & & $\mathrm{M}$ & $\mathrm{F}$ & $\mathrm{M}$ & $\mathrm{F}$ & $\mathrm{M}$ & $\mathrm{F}$ & $\mathrm{M}$ & $\mathrm{F}$ & $\mathrm{M}$ & $\mathrm{F}$ & & \\
\hline \multirow{2}{*}{ SSTs } & Urban & 5 & 5 & 25 & 25 & 20 & 15 & 5 & 5 & 10 & 5 & 120 & \multirow{2}{*}{400} \\
\hline & Rural & 5 & 5 & 100 & 55 & 25 & 10 & 45 & 20 & 10 & 5 & 280 & \\
\hline
\end{tabular}

SSTs: Secondary School Teachers, FC: Federal Capital

\section{Instrument of the Study}

A self-reporting questionnaire on seven indicators of content knowledge of IPS as per professional standards was developed to measure the existing levels of in-service teachers teaching secondary classes. 50 statements were designed on 5 point Likert scale based upon Content knowledge of IPS. The questionnaire focused aims, goals and objectives of education, planning instruction for daily classroom teaching, ability to design short and long-term plans which are based on subject content, curriculum related goals, students relationship with community, competence in using multiple strategies with respect to students' age, promote the problem solving and critical thinking skills. Further the teachers were asked to prioritize the seven indicators of content knowledge of IPS according to their professional development needs. 


\section{Validity and Reliability}

The content validation of the questionnaire was determined by a group of experts from the related field, their suggestions were incorporated in the final instrument. Reliability was calculated through Cronbach alpha after the pilot testing which was $\alpha=.92$ of the instrument as a whole and indicator wise reliability is as follows:

Table 3

Indicator wise reliability of items of content knowledge of IPS

\begin{tabular}{|c|c|c|c|}
\hline Sr.No. & Indicators & Items & $\alpha$ \\
\hline 1. & $\begin{array}{l}\text { The aims, goals and objectives of } \\
\text { education }\end{array}$ & 5 & .70 \\
\hline 2. & $\begin{array}{l}\text { Principles of acquisition of reading, } \\
\text { writing and arithmetic at different stages } \\
\text { of development }\end{array}$ & 2 & .72 \\
\hline 3. & $\begin{array}{l}\text { Availability of appropriate resources for } \\
\text { instruction }\end{array}$ & 12 & .67 \\
\hline 4. & $\begin{array}{l}\text { To plan instructional strategies based on } \\
\text { students' needs }\end{array}$ & 8 & .74 \\
\hline 5. & $\begin{array}{l}\text { Development and use of a variety of } \\
\text { instructional method }\end{array}$ & 6 & .67 \\
\hline 6. & $\begin{array}{l}\text { The effect of out of school activities } \\
\text { including homework }\end{array}$ & 4 & .69 \\
\hline 7. & $\begin{array}{l}\text { Methods of teaching and classroom } \\
\text { management }\end{array}$ & 13 & .72 \\
\hline Total & & 50 & .92 \\
\hline
\end{tabular}

\section{Data Analysis}

To identify the gap between the prevailing levels of content knowledge of IPS of teachers teaching secondary classes and the required level prescribed in the professional standard a 5 point Likert scale was used for data collection, arbitrary values were given for each level, subsequently; never denoted level 1, rarely depicted level 2, sometimes showed level 3, often reflected level 4 and always represented level 5 which was the level to be achieved by the teachers of secondary schools according to the prescribed professional standard. 


\section{Results/ Findings}

Table 4

Strata wise levels of content knowledge of IPS

\begin{tabular}{|c|c|c|c|c|c|c|c|c|c|c|c|c|c|c|c|c|c|c|c|c|}
\hline & \multicolumn{4}{|c|}{$\begin{array}{c}\text { Never } \\
\text { L } 1\end{array}$} & \multicolumn{4}{|c|}{$\begin{array}{c}\text { Rarely } \\
\text { L } 2\end{array}$} & \multicolumn{4}{|c|}{$\begin{array}{c}\text { Sometimes } \\
\text { L } 3\end{array}$} & \multicolumn{4}{|c|}{$\begin{array}{l}\text { Often } \\
\text { L } 4\end{array}$} & \multicolumn{4}{|c|}{$\begin{array}{c}\text { Always } \\
\text { L } 5\end{array}$} \\
\hline & & $\begin{array}{l}\mathrm{M} \\
\%\end{array}$ & $\begin{array}{l}\mathrm{F} \\
\%\end{array}$ & & & M & & $\begin{array}{l}\mathrm{F} \\
\%\end{array}$ & & $\begin{array}{l}\mathrm{M} \\
\%\end{array}$ & & & & $\%$ & 0 & & & $\begin{array}{l}\text { M } \\
\%\end{array}$ & & $\begin{array}{l}\mathrm{F} \\
\%\end{array}$ \\
\hline Indicators & $\begin{array}{l}\mathrm{U} \\
50\end{array}$ & $\begin{array}{l}\mathrm{R} \\
147\end{array}$ & & $\mathrm{R}$ & $\begin{array}{l}\mathrm{U} \\
50\end{array}$ & & & $\begin{array}{l}\mathrm{R} \\
91\end{array}$ & $\begin{array}{l}\mathrm{U} \\
50\end{array}$ & $\begin{array}{c}\mathrm{R} \\
147\end{array}$ & $\begin{array}{l}\mathrm{U} \\
57\end{array}$ & $\begin{array}{l}\mathrm{R} \\
91\end{array}$ & $\begin{array}{l}\mathrm{U} \\
50\end{array}$ & $\begin{array}{c}\mathrm{R} \\
147\end{array}$ & $\begin{array}{l}\mathrm{U} \\
57\end{array}$ & $\begin{array}{l}\mathrm{R} \\
91\end{array}$ & $\begin{array}{l}\mathrm{U} \\
50\end{array}$ & $\begin{array}{c}\mathrm{R} \\
147\end{array}$ & $\begin{array}{l}\mathrm{U} \\
57\end{array}$ & $\begin{array}{l}\mathrm{R} \\
91\end{array}$ \\
\hline 1. & 0 & 2 & 2 & 1 & 9 & 6 & 7 & 7 & 40 & 32 & 31 & 29 & 32 & 31 & 39 & 29 & 19 & 28 & 22 & 33 \\
\hline 2. & 2 & 5 & 5 & 6 & 7 & 11 & & 12 & 31 & 41 & 36 & 40 & 40 & 30 & 38 & 29 & 20 & 13 & & 13 \\
\hline 3. & 3 & 4 & 4 & 4 & 7 & 10 & 7 & 10 & 26 & 26 & 25 & 26 & 39 & 32 & 35 & 31 & 24 & 27 & 29 & 29 \\
\hline 4. & 2 & 0 & 0 & 1 & 3 & 5 & 2 & 4 & 24 & 21 & 17 & 20 & 45 & 37 & 47 & 38 & 26 & 36 & & 36 \\
\hline 5. & 2 & 0 & 1 & 1 & 2 & 4 & 1 & 3 & 18 & 17 & 27 & 18 & 49 & 38 & 38 & 39 & 28 & 40 & 33 & 39 \\
\hline 6. & 0 & 0 & 0 & 0 & 2 & 3 & 52 & 2 & 19 & 17 & 19 & 16 & 43 & 35 & 37 & 32 & 35 & 44 & 39 & 49 \\
\hline 7. & 5 & 5 & 6 & 5 & 5 & 9 & 7 & 9 & 23 & 20 & 22 & 22 & 40 & 32 & 33 & 27 & 27 & 33 & & 37 \\
\hline
\end{tabular}

SSTs: Secondary School teachers, L: Level

Table 4 reveals the percentage of SSTs on each indicator according to the five levels. In the light of the prescribed standard; level 5 is the desired level which all the SSTs must possess in order to provide quality teaching. This level also establishes the difference in percentages between the SSTs who have the competency in content knowledge of IPS and those who are lacking behind at different preceding levels.

Indicator 1: Strata wise only 19\% urban male, $28 \%$ rural male, $22 \%$ urban female and 33\% rural female SSTs had the knowledge of aims, goals and objective of education, the remaining $81 \%$ urban male, $72 \%$ rural male, $78 \%$ urban female and $67 \%$ rural female SSTs were at different levels and required professional development trainings to achieve competency. 
Indicator 2:Inthe knowledge of principles of acquisition of reading, writing \& arithmetic $20 \%$ urban male, $13 \%$ rural male, $11 \%$ urban female and $13 \%$ rural female SSTs were competent, the rest of $80 \%$ urban male, $77 \%$ rural male, $89 \%$ urban female and $77 \%$ rural female SSTs were at different levels and required professional development trainings to display desired competency.

Indicator 3: The competency level of $24 \%$ urban male, $27 \%$ rural male, 29\% urban female and 29\% rural female SSTs was acceptable in the knowledge related to availability of appropriate resources and materials for instruction, whereas $76 \%$ urban male, $73 \%$ rural male, $71 \%$ urban female and $71 \%$ rural female SSTs needed professional development in this area at varying degrees.

Indicator 4: Only 26\% urban male, 36\% rural male, 33\% urban female and $36 \%$ rural female SSTs knew about planning instructional strategies based on students' needs, while the other $74 \%$ urban male, $64 \%$ rural male, $67 \%$ urban female and $64 \%$ rural female SSTs were in need of professional development on this indicator.

Indicator 5: Strata wise merely $28 \%$ urban male, $40 \%$ rural male, $33 \%$ urban female and 39\% rural female SSTs had the knowledge of development and use of a variety of instructional method, the remaining $72 \%$ urban male, $60 \%$ rural male, $67 \%$ urban female and $61 \%$ rural female SSTs were at different levels and required professional development trainings to achieve competency.

Indicator 6: In the knowledge related to the effect of out of school activities including homework; 35\% urban male, 44\% rural male, 39\% urban female and $49 \%$ rural female SSTs were competent, the rest of $65 \%$ urban male, 56\% rural male, $61 \%$ urban female and $51 \%$ rural female SSTs were at different levels and required professional development trainings to display desired competency.

Indicator 7: The competency level of $27 \%$ urban male, $33 \%$ rural male, $32 \%$ urban female and $37 \%$ rural female SSTs was acceptable in the knowledge related to methods of teaching and classroom management, whereas $73 \%$ urban male, $67 \%$ rural male, $68 \%$ urban female and $63 \%$ rural female SSTs needed professional development in this area at varying degrees.

Prioritization of professional development areas according to the indicators of content knowledge of IPS for teachers teaching secondary 
classes was done on the bases of percentage of SSTs prioritizing the given areas according to their felt needs.

Table 5

Priority wise areas of professional development of content knowledge of IPS

\begin{tabular}{clc}
\hline PD Areas & \multicolumn{1}{c}{ Indicators } & $\begin{array}{c}\text { \% SSTs } \\
\text { prioritization }\end{array}$ \\
\hline P1 & $\begin{array}{l}\text { Development of aims, goals and objectives } \\
\text { P2 }\end{array}$ & $\begin{array}{l}\text { Planning of out of school activities } \\
\text { including homework for meaningful... }\end{array}$ \\
P3 & $\begin{array}{l}\text { To plan instructional strategies based on } \\
\text { students' needs }\end{array}$ & 25 \\
P4 & $\begin{array}{l}\text { Availability of appropriate resources and } \\
\text { materials for instructional .... }\end{array}$ & 18 \\
P5 & $\begin{array}{l}\text { Development and use of a variety of } \\
\text { instructional method ..... }\end{array}$ & 18 \\
P6 & $\begin{array}{l}\text { Methods of classroom assessment and } \\
\text { management. }\end{array}$ & 15 \\
P7 & $\begin{array}{l}\text { Principles of acquisition of reading, } \\
\text { writing and arithmetic... }\end{array}$ & 14 \\
\hline
\end{tabular}

SSTs: Secondary school teachers, IPS: Instructional planning \& strategies, PD: Professional Development, P: Priority

Table 5 highlights the areas of content knowledge of IPS in which SSTs demand training from most prioritized to the least according to their felt needs.

The difference between male \& female SSTs on seven indicators of content knowledge of IPS was calculated by applying independent sample t-test. 
Table 6

Difference between male \& female SSTs on 7 indicators of content knowledge of IPS

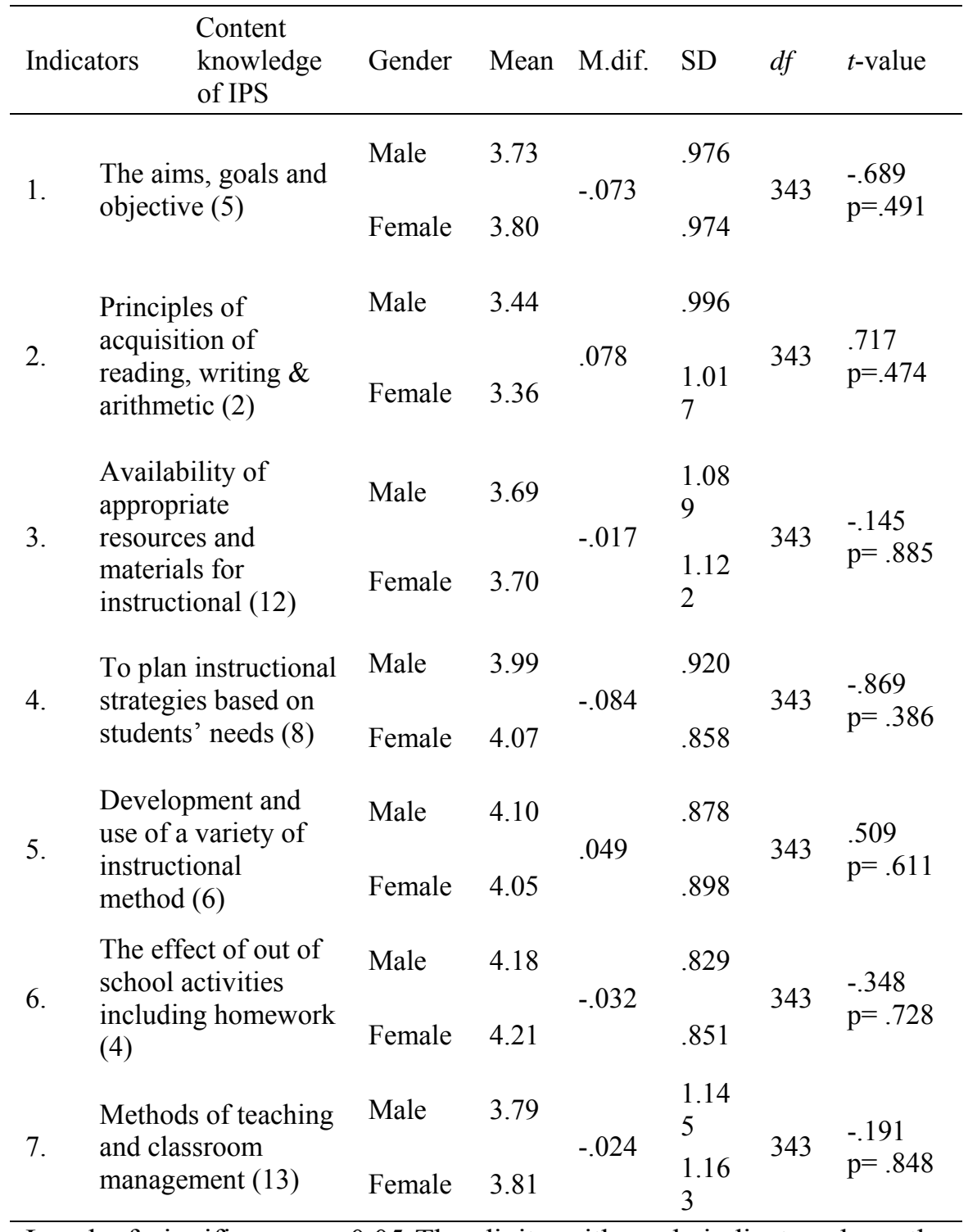

Level of significance $\mathrm{p}<0.05$-The digits with each indicator show the number of items for that indicator 
Table 6 shows no significant difference between male and female SSTs on any indicator of content knowledge of IPS. Thus $\mathrm{H}_{0}$ is accepted.

Independent sample t-test was used to find out the difference between the urban \& rural SSTs on seven indicators of content knowledge of IPS.

Table 7

Difference between the urban \& rural SSTs on 7 indicators of content knowledge of IPS

\begin{tabular}{|c|c|c|c|c|c|c|c|}
\hline $\begin{array}{l}\text { Indica } \\
\text { tors }\end{array}$ & $\begin{array}{l}\text { Content knowledge of } \\
\text { IPS }\end{array}$ & Location & Mean & M.dif. & $\mathrm{SD}$ & $d f$ & $t$-value \\
\hline \multirow[t]{2}{*}{1.} & \multirow[t]{2}{*}{$\begin{array}{l}\text { The aims, goals and } \\
\text { objective ( } 5 \text { ) }\end{array}$} & Urban & 3.75 & \multirow[t]{2}{*}{-.035} & .960 & \multirow[t]{2}{*}{343} & \multirow[t]{2}{*}{$\begin{array}{l}-.328 \\
p=.743\end{array}$} \\
\hline & & Rural & 3.78 & & .997 & & \\
\hline \multirow[t]{2}{*}{2.} & \multirow{2}{*}{$\begin{array}{l}\text { Principles of } \\
\text { acquisition of reading, } \\
\text { writing \& arithmetic(2) }\end{array}$} & Urban & & \multirow[t]{2}{*}{.086} & 1.010 & \multirow[t]{2}{*}{343} & \multirow{2}{*}{$\begin{array}{l}.783 \\
p=.434\end{array}$} \\
\hline & & Rural & 3.35 & & .999 & & \\
\hline \multirow[t]{2}{*}{3.} & \multirow{2}{*}{$\begin{array}{l}\text { Availability of } \\
\text { appropriate resources } \\
\text { and materials for } \\
\text { instructional (12) }\end{array}$} & Urban & 3.70 & \multirow[t]{2}{*}{.022} & 1.102 & \multirow[t]{2}{*}{343} & \multirow[t]{2}{*}{$\begin{array}{l}.181 \\
p=.856\end{array}$} \\
\hline & & Rural & 3.68 & & 1.104 & & \\
\hline \multirow[t]{2}{*}{4.} & \multirow{2}{*}{$\begin{array}{l}\text { To plan instructional } \\
\text { strategies based on } \\
\text { students' needs ( } 8 \text { ) }\end{array}$} & Urban & 4.03 & \multirow[t]{2}{*}{-.002} & .875 & \multirow[t]{2}{*}{343} & \multirow{2}{*}{$\begin{array}{l}-.020 \\
p=.984\end{array}$} \\
\hline & & Rural & 4.03 & & .921 & & \\
\hline \multirow{2}{*}{5.} & \multirow{2}{*}{$\begin{array}{l}\text { Development and use } \\
\text { of a variety of } \\
\text { instructional } \\
\text { method (6) }\end{array}$} & Urban & 4.04 & \multirow{2}{*}{-.094} & .886 & \multirow{2}{*}{343} & \multirow{2}{*}{$\begin{array}{l}-.973 \\
p=.331\end{array}$} \\
\hline & & Rural & 4.13 & & .886 & & \\
\hline \multirow[t]{4}{*}{6.} & \multirow{2}{*}{$\begin{array}{l}\text { The effect of out of } \\
\text { school activities } \\
\text { including } \\
\text { homework (4) }\end{array}$} & Urban & 4.19 & \multirow[t]{2}{*}{.001} & .833 & \multirow[t]{2}{*}{343} & \multirow{2}{*}{$\begin{array}{l}.016 \\
p=.987\end{array}$} \\
\hline & & Rural & 4.19 & & .847 & & \\
\hline & \multirow{2}{*}{$\begin{array}{l}\text { Methods of teaching } \\
\text { and classroom } \\
\text { management (13) }\end{array}$} & Urban & 3.81 & \multirow[t]{2}{*}{.026} & 1.142 & \multirow[t]{2}{*}{343} & \multirow{2}{*}{$\begin{array}{l}.205 \\
p=.837\end{array}$} \\
\hline & & Rural & 3.78 & & 1.168 & & \\
\hline
\end{tabular}

Level of significance $\mathrm{p}<0.05$ - The digits with each indicator show the number of items for that indicator 
Table 7reveals no significant difference between urban \& rural SSTs on any of the 7 indicator of content knowledge of IPS. Thus $\mathrm{H}_{0}$ is accepted.

\section{Data Triangulation}

To ensure the validity of the study, data triangulation was done. Out of the 400 SSTs selected for questionnaire 80 were observed according to an observation checklist; out of those 80,40 were further interviewed according to a structured interview on the indicators of content knowledge of IPS. The data was quantified and Spearman's Rho was applied to find out the rank order correlation among the three sources of data.

Table 8

Spearman's Rho for data triangulation of content knowledge of IPS

\begin{tabular}{lcc}
\hline Data Sources & Self-report & Observation \\
\hline \multirow{2}{*}{ Observation } & .83 & \\
& $(.04)$ & 1 \\
Interview & .49 & .55 \\
& $(.32)$ & $(.26)$ \\
\hline
\end{tabular}

Level of significance $\mathrm{p}<0.05$

Table 8 accentuates that the self-report of SSTs was consistent with their observation, but they over projected themselves in interview which contradicted with their observation as well as self-report.

\section{Discussion}

The existing levels of content knowledge of IPS revealed that majority of urban male teachers on indicator 1 were placed at level three on the continuum of five levels and at level four on rest of the 6indicators. The rural male showed variation as majority of them were on level three on indicator 1 and 2, level four on indicator 3 and 4 and level five on indicator 5,6 and 7. According to urban female teachers majority of them were at level four on indicator $1,2,3,4,5$ and 7, only on indicator 6 majority of them achieved level five the highest level. Most of the rural female teachers were at the highest level on indicator 1, 6 and

7, on indicator 3, 4 and 5 they obtained level four and only on indicator 2 
they were at level three. The highest and expected was level five. Level three was the average level among the five levels. It is encouraging that none of the teachers were found at level 1 and 2 on any of the content knowledge of IPS indicators. Though the scenario is not very discouraging, even then all the SSTs need robust in-service professional trainings to update themselves according to the seven indicators of content knowledge of IPS related to the objectives, aims and goals of curriculum. They need to know how the acquisition of principles of reading, writing and arithmetic at different stages of development is made possible. They lack the planning of instructional material and instructional technology, developing instructional material, methods and environment for the purpose of learning.

These results are similar to the findings of Atta, Aziz, Hassan \& Ahmad (2012) which revealed that the teachers in public schools in Pakistan require rigorous training in instructional planning and assessment techniques. This may be due to the fact that both the researches were conducted in the same context focusing similar respondents.

In the present study no difference was found between the content knowledge of IPS of male \& female SSTs which was contradictory to the results of researches conducted by Shakir \& Adeeb (2014) and Laird, Garver, \& Niskodé, (2007)which showed difference in the IPS of male and female teachers. This may be because both these studies focused the IPS practices of male and female teachers whereas, the current study highlighted content knowledge of IPS of these teachers which shows that irrespective of variation in content knowledge of IPS possessed by teachers their practices tend to differ which supports the claim that male and female teachers react differently to given challenges.

Moreover, no difference was observed between the content knowledge of IPS of urban \& rural SSTs. These findings are supported by Shambaugh (2008) who also found no significant difference between rural \& urban teachers on any school related variable but were contradictory to the findings of Ali \& Halai (2010) that revealed difference between the inclination of urban and rural teachers towards the use of professional standards including instructional planning and strategies. This supports the premise that urban teachers have abundant opportunities of professional development therefore they are more receptive of new initiatives in the field of education whereas, the teachers of rural areas are deprived of equal opportunities and that reflect in their level of acceptance. 


\section{Conclusion}

On the basis of the findings of the study it was concluded that:

- A relatively greater number of rural female teachers had comprehensive knowledge of aims, goals and objectives of education.

- Regarding the knowledge of principles of acquisition of reading, writing \& arithmetic skills at different stages of development, reasonably more urban male and female teachers were at the second highest level.

- According to the knowledge about availability of appropriate resources and use of materials for instructional planning \& strategies based on students' needs, comparatively more urban (male \& female) as well as rural (male $\&$ female) teachers were at the second highest level.

- Reasonably more rural male teachers were at the highest level in the knowledge about development and use of a variety of instructional method.

- Comparatively more rural male, rural female and urban female teachers were competent in arranging out of school activities including homework.

- More rural male \& female teachers had excellent knowledge of methods of teaching and classroom management than others.

- Over all the situation is not very discouraging as majority $65 \%$ teachers were at the second highest level on 1 to 7 indicators of content knowledge of IPS, $25 \%$ teachers were at the highest level on indicators 1, 5, 6 and 7 and only $11 \%$ teachers were at average level on just the first two indicators of content knowledge of IPS.

- There was no significant difference between male \& female or urban $\&$ rural teachers on any of the seven indicators of content knowledge of IPS but they all were below the required standard.

\section{Recommendations}

Teachers teaching secondary classes may be provided in-service professional development trainings in the seven areas of content knowledge of IPS according to their needs; for acquiring the required standard as aspired by the professional standards for teachers in Pakistan. The followings areas for professional development are recommended on the basis of preferences given by in-service teachers regarding training 
programs. According to them priority may be given to development of aims, goals and objectives of education, then arranging of out of school activities including homework for meaningful learning, after that planning instructional strategies based on students' needs may be focused, subsequently availability of appropriate resources and materials for instructional planning may be preferred, next development and use of a variety of instructional methods may be included followed by methods of classroom assessment and management and finally principles of acquisition of reading, writing and arithmetic at different stages of development may be strengthened through in-service professional development programs. 


\section{References}

Amirali, M., Halai, A. (2010). Teachers' knowledge about the nature of mathematics: A survey of secondary school teachers in Karachi, Pakistan. Bulletin of Education and Research, 32(2), 45-61.

Atta, N., Aziz, S., Hassan, H., \& Ahmad, N. C. (2012). National Professional Standards for Teachers and Classroom Practices. Language in India: Strength for Today and Bright Hope for Tomorrow, 12, 468-476.

Darling-Hammond, L. (2003). The effects of initial teacher education on teacher quality. Paper presented at the Australian Council for Educational Research (ACER) Research Conference 2003. Melbourne

Eggen, P., \& Kauchak, D. (2001). Educational psychology: Windows on classrooms. New Jersey Prentice Hall, Inc.

Kardia, D.B. \& Wright, M.C. (2004). Instructor identity: The impact of gender and race on faculty experiences with teaching. Occasional Paper, University of Michigan Center for Research on Learning and Teaching.

Kuh, G. D., Nelson Laird T. F., \& Umbach, P. D. (2004). Aligning faculty and student behavior: Realizing the promise of Greater Expectations. Liberal Education, 90(4), 24-31.

Lee, J. (2010). Exploring kindergarten teachers' pedagogical content knowledge of mathematics: Department of Curriculum and Instruction-EC College of Education and Health Professional, University of Texas at Arlington, Science Hall

Ministry of Education. (2009). National Professional Standards for Teachers in Pakistan. Islamabad: Government of Pakistan.

National Survey of Student Engagement. (2005). Exploring different dimensions of student engagement. Bloomington, IN: Indiana University Center for Postsecondary Research. 
Nelson Laird, T. F., Garver, A. K., \& Niskodé, A. S. (2007). Gender gaps:Understanding teaching style differences between men and women. Kansas City, MO: Association for Institutional Research.

Rao, R. R. (2004). Methods of Teacher Training. New Dehli: Discovery Publishing House.

Shakir, M., \& Adeeb, M. A. (2014). Performance Appraisal: An evaluation of teachers' competencies based on national professional standards in Pakistan. International Review of Social Sciences, 2(12), 532-539.

Shambaugh, W. R. (2008). 'Teacher Self-efficacy, Collective Teacher Efficacy, Automatic Thoughts, States of Mind, and Stress in Elementary School Teachers.' PCOM Psychology Dissertations. Paper 126.

Ukeje. (2008).Teacher's Registration Council of Nigeria. Revised Guideline for Teachers Registration. Abuja: NERDC.

\section{Citation of this Article:}

Rizwan, S., \& Masrur, R. (2019). Need assessment for the professional development of teachers in content knowledge of instructional planning and strategies. Pakistan Journal of Education, 36(1), 99-118. 